\title{
Does Money Fly? The Economic Value of Migratory Birdwatching in Xochimilco, Mexico
}

\author{
Daniel A. Revollo-Fernández \\ Becario del Programa de Becas Posdoctorales en la UNAM, Centro Regional de Investigaciones \\ Multidisciplinarias, Universidad Nacional Autónoma de México (UNAM), Mexico City, Mexico \\ Email: drevollofer@gmail.com, dalfredo@correo.crim.unam.mx
}

Received 4 May 2015; accepted 5 June 2015; published 8 June 2015

Copyright (C) 2015 by author and Scientific Research Publishing Inc. This work is licensed under the Creative Commons Attribution International License (CC BY). http://creativecommons.org/licenses/by/4.0/ c) (i) Open Access

\begin{abstract}
This paper estimates the economic value that national and international birdwatchers have to keep an urban wetland in this case, Xochimilco (Mexico), as a place of rest, food and/or shelter for migratory birds from North America. For this purpose, it is resorted to surveys and contingent valuation that estimates the willingness to pay (WTP) per year of these watchers. The best estimate indicates that national watchers are willing to pay approximately US \$79 per year, while international, US \$296. Using these estimates, it is calculated that the economic value of the bird migration environmental service for this urban wetland is located between US \$2836 and US \$3999 per hectare. This found value can work as an input for decision makers when faced with projects and/or policies that may face different objectives.
\end{abstract}

\section{Keywords}

Contingent Valuation, Migratory Birdwatching, Urban Wetland, Xochimilco

\section{Introduction}

The US Fish and Wildlife Service defines birdwatcher as an individual who takes a trip a mile or more from their residence to another place with the primary purpose of watching birds and/or the individual who is dedicated to observation of these around its home, but with the main reason of identifying them [1]. The US Fish and Wildlife Service estimated that for the year 2011, in the United States there were approximately 47 million birdwatchers older than 16 years, of which $20 \%$ left their country to perform such activities as ecotourism [1]. Also, birdwatching in the United States for that year generated about 40,942,000 dollars directly, 666,000 jobs 
and $\$ 106,977,000$ of economic benefit indirectly [1]. In the case of Canada, birdwatching generated, for the year 2000, about \$256 million; while for the case of Costa Rica, about 410 million dollars by the year 1999 [2].

It is reported that the annual economic impact for 2006 in Mexico for the activity of bird catching was US $\$ 442,000$ [2]. While Cantu, Gómez de Silva and Sanchez estimate that birdwatching generated the country at least US \$23.9 million, with approximately 78 thousand birdwatchers, mostly foreigners who came to Mexico [2].

Mexico is considered the fifth megadiverse country in the world, after Indonesia and before Venezuela, as part of the select group of nations possessing the greatest number and diversity of animals and plants [3]. In the case of birds, of the 10,500 species of birds that have been reported in the world, 1123 - 1150, about $11 \%$ live in Mexico [4]. It is believed that of all species in Mexico, 194 - 212 are endemic [3]-[6]. Therefore, Mexico is considered the eleventh place according to its bird population at a world level, the second highest number of endemic species in America [2] and the fourth among the countries considered megadiverse [4]; however, this environmental service is still not sustainably exploited.

Around the world, people have noted with interest the emergence and temporary disappearance of many species of birds [4]. This appearance and disappearance of birds are mainly due to the migration; they perform with seasonal changes. The main factor to explain this migratory behavior of birds is the dramatic decrease in food availability [7] [8]. Generally, in North America (US and Canada), four major migration routes are recognized: 1) the route of the Centre, 2) the route of Mississippi, 3) the route of the Atlantic and 4) the route of the Pacific [8] [9]. Three of these routes $(1,3,4)$ pass through parts of Mexico; in that sense, these places are for resting, feeding and/or the reproduction of many species.

The route of the Center, which gathers birds from large American meadows, passes Mexico through the Sierra Madre Oriental-Occidental and Altiplano Central [10]. In the passage of the Altiplano Central of Mexico, a crossing place of Mexico City and the surrounding areas, these birds will feed, breed, rest and/or take shelter in the Protected Natural Area of ejidos of Xochimilco and San Gregorio Atlapulco that comprises an area of 2657 hectares where the famous Chinampas exist, which are highly productive prehispanic agricultural systems composed of artificial islands. Xochimilco is one of the last remaining urban wetlands in the area, which has a great importance for the survival of birds [11]-[14]. According to ornithological studies, Xochimilco has a wealth of birds amounting to about 212 species, among which there are both waterbirds and terrestrial, both in Chinampas and in the Wetland [15]. Of these 212 species, 57 have been found to nest in the area and approximately 90 of them are migratory, most of which come from Canada and the United States [14]. Xochimilco, as well as its birds, has been threatened by many factors, such as the invasion of urbanization which makes their permanence and conservation difficult [16].

It demonstrates the great importance of these urban wetlands for conservation and observation of many species of birds, both migratory and local, especially in the Natural Protected Area of ejidos of Xochimilco and San Gregorio Atlapulco. An economic assessment of the existence of Xochimilco is required from a point of view of a place of rest, shelter, reproduction and/or food for migratory birds. Therefore, what this work intends is to estimate this value from the point of view of how much the willingness is to pay (WTP) of birdwatchers, foreign and national (US and Canadian) for conservation of wetlands and Chinampas that exist in Xochimilco as a resting place, shelter, reproduction and/or food for migratory birds coming from North America. The work is divided into five parts—a literature review, methods, results, discussion and conclusions.

\section{Literature Review}

The application of economic techniques for valuation of the existence or preservation of some species of birds or any activity related to them is limited, and even more when studying their migration [17]. Kaval \& Roskruge conducted an extensive literature review summarizing the available studies through 2007 [40]; including new studies from 2008 through 2010 resulted in approximately 50 bird valuation studies. These studies focused on the economic valuation of specific bird species [18] [19] and/or bird subjects, in general, such as the importance of their environment [20] [21], its presence importance for some productive activities [22] or the diversity of bird species [23]. Only about seven percent of the studies reviewed are intended solely for estimating the economic value of bird migration [17] [24] (more detail, see Appendix 1).

The first study found in the literature, based on the economic value of birds, is prepared by Hammack \& Brown in 1974 [24]. They estimate, through the contingent valuation technique, that people have a willingness to pay (WTP) equal to \$25 USD for migrating of waterbirds occurring in the route of the Pacific (prices of 2014). 
In the case of migration of birds in the Netherlands, Brouwer et al. [17] and Sultatian \& Van Beukering [25] it estimates that people have a WTP of 36 and 31 USD respectively (prices of 2014). While Boyle et al. [26] estimated a value for the WTP equal to \$149 USD for the case of migration that occurs in the central route of America. The WTP varies depending on the species, and/or related activity. On the other hand, it appears that a majority of these studies uses the contingent valuation technique, and to a lesser extent, the cost-benefit analysis [23] [24] [27] or travel costs [21] [28] [29].

In the case of Mexico, the literature on estimating the economic value of birds is almost zero, except the study by Cantú Gómez de Silva and Sanchez [2]. They estimate that the economic impact of bird watching activity in Mexico is approximately equal to 23.9 million US dollars, which are mainly generated by foreign watchers.

In that sense, it may highlight and confirm the scarcity of studies where the WTP of people is estimated for the phenomenon of bird migration [17] and/or places that serve as resting, feeding or shelter for migratory birds, as with the case of the Protected Natural Area of ejidos of Xochimilco and San Gregorio Atlapulco located in Mexico City.

\section{Methods}

The data used in this study was generated through the use of surveys to birdwatchers, both national and international, in order to study the willingness to pay (WTP) for the conservation of wetlands and Chinampas in Xochimilco, Mexico as a place for resting and feeding for migratory birds from North America. After the implementation of the survey, a selection of variables was performed to finally bring a logistical econometric model for calculating the WTP of birdwatchers.

\subsection{Study Area}

The Lakeside System of Ejido Xochimilco and San Gregorio Atlapulco is located in the central-southern part of Mexico City, Mexico and has an area of approximately 2657 ha [15] (Figure 1). Due to its adjacency with the urban area, there is strong pressure within the site, so there is presence of irregular human settlements, the population living in this area is estimated to be 24,100 inhabitants and in the area of immediate influence 121,130 inhabitants [15] [16] [30]. Also, the lakeside system, declared it a protected natural area, it is located in the so-called soil conservation, it constitutes a remnant ecosystem of the Basin of Mexico formed by natural flooded plains and induced water bodies [16] [31].

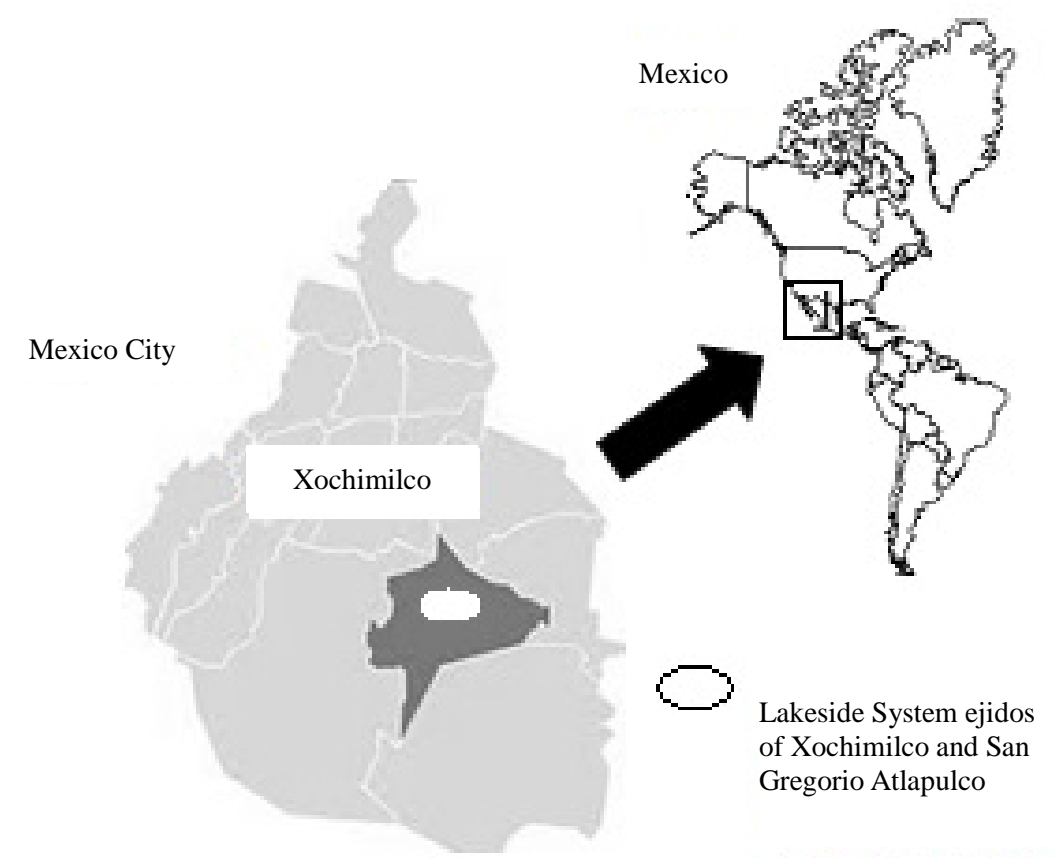

Figure 1. Lakeside system ejidos of Xochimilco and San Gregorio Atlapulco, Mexico. 
It offers a wealth of flora and fauna, both aquatic and terrestrial 146 species of flora have been recorded, distributed in 101 genera and 45 families [15]. The aquatic vegetation is represented by 115 species, distributed in 63 genera. In the case of species of wildlife, it is composed of 272 species, 21 fish, 6 amphibians, 10 reptiles, 23 mammals and 212 wild birds [15]. Of these last, 80 species typically associated with aquatic or wetland environments single out [13]. Xochimilco is also an important area for migratory birds, since it has been found that they arrive there 90 species, mainly in the winter from Canada and the United States through the Center route, seeking rest, food and reproduction. Among the main migratory birds that come to the place, we have the white pelican (Pelecanus erythororhynchos), the olive cormorant (Phalacrocorax auritus), and several gulls and terns [13] [14] (Figure 2).

Also, this place has been important since pre-Hispanic times for the center of the country due to the agricultural production by creating Chinampas (rectangular islands built of layers of aquatic vegetation, rocks and lake mud, on an interwoven carpet submerged in shallow waters, supported by fenced poles and ahuejote trees to prevent erosion) as a unique crop manner considered and highly efficient in the world [15] [32]. For all this, the Lakeside System of ejidos Xochimilco and San Gregorio Atlapulco in addition to being considered a protected area, it is declared a RAMSAR site (2004) and is part of the recognition of the United Nations for Education, Science and Culture (UNESCO) as a Cultural and Natural World Heritage (1987) (Historic Center and Xochimilco Chinamperas Areas, San Gregorio Atlapulco and San Luis Tlaxialtemalco) [32].

\subsection{Number of Sample and Survey}

Two surveys were designed, one aimed at national birdwatchers (residing in Mexico) and one for international (Canadian and US residents) because both groups are directly or indirectly benefiting the conservation of wetlands and Chinampas of Xochimilco (more detail on the survey, see Appendix 2). In the first case, the national birdwatchers can go directly to Xochimilco to observe water and terrestrial birds, both migratory and native; while in the second case, international birdwatchers get benefits because migratory birds come to Xochimilco from the United States and Canada, leaving their homes in winter in search of food, rest and/or shelter. In total 734 surveys were applied, 358 to national birdwatchers and 376 to international (Table 1). These surveys were applied during the months of February to May 2014 through groups of birdwatchers on social networks and national and international forums. Before the implementation of the final survey, a pilot test was carried out in November and December 2013 in order to test whether the questions were properly raised and to investigate the range that the question on willingness to pay for the conservation of wetlands and Chinampas of Xochimilco among birdwatchers might have.

The final survey for both national and international birdwatchers is divided into three sections. The first where it asks general aspects of bird watching activity performed by each respondent. In the second section, there is an explanation of the importance of Xochimilco in the flyway of birds from North America to Central and South America to then ask the respondent about aspects of bird watching in Xochimilco and their willingness to pay for conservation of this place. Finally, the third part is destined to find out socioeconomic aspects.

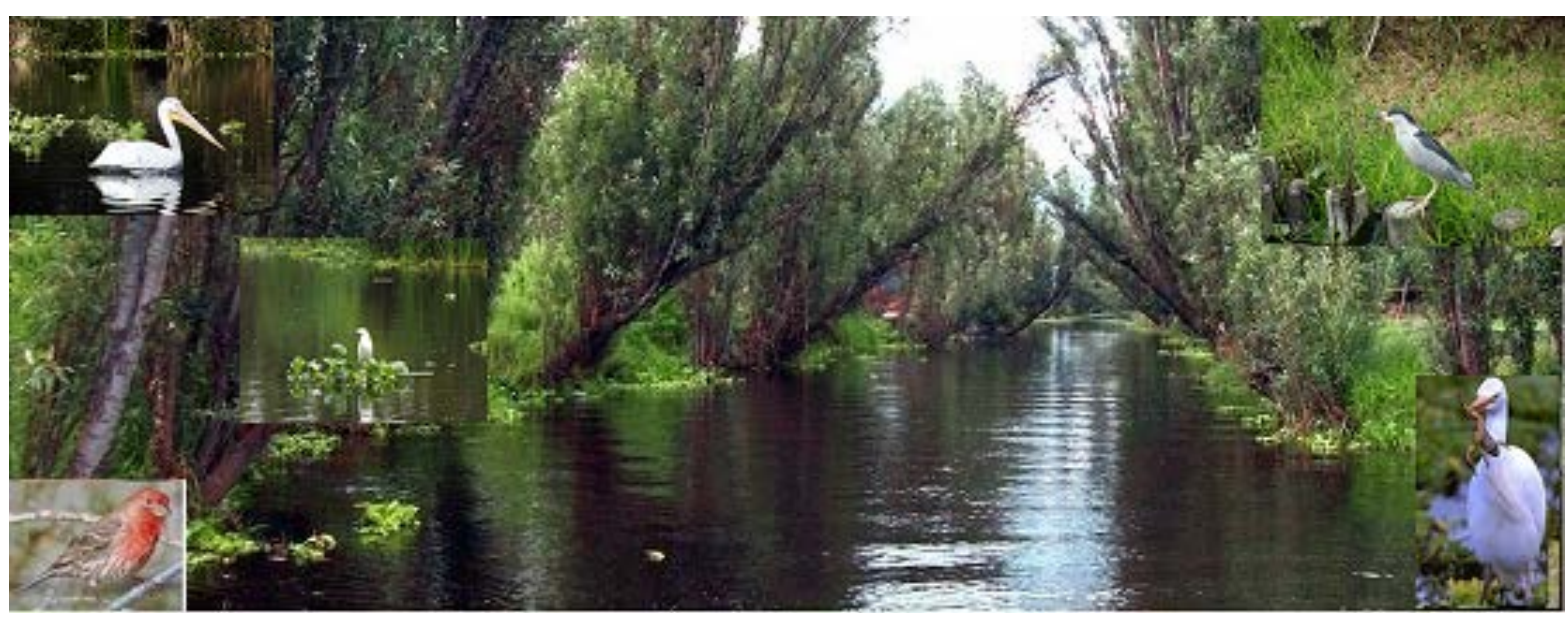

Figure 2. Birds and landscape (Chinampas) — ejidos of Xochimilco and San Gregorio Atlapulco, Mexico. 
Table 1. Number of sample considered for the study.

\begin{tabular}{cccc}
\hline National & 358 & & $48.80 \%$ \\
& 376 & & $51.20 \%$ \\
International & Canada & 78 & $20.70 \%$ \\
& United States & 298 & $79.30 \%$ \\
TOTAL & $734^{*}$ & & $100 \%$ \\
\hline
\end{tabular}

*For the year 2006, according to Cantu et al. 78,000 birdwatchers in Mexico have been recorded, national and international [2]. In that sense, taking the number of observers as a sample, considering a marginal error of $5 \%$ and a confidence level of $95 \%$, the final sample should be at least 383 surveys. However, performing 734 surveys, the marginal error decreases to $3.6 \%$, with a confidence level of $99.4 \%$.

\subsection{Selection of Variables}

Through the surveys applied, about thirty variables were obtained for both the case of national and international birdwatchers; of which a selection for the estimation of the econometric model and the statistical analysis was performed. In the case of explained or dependent variables it is considered one, both in the case of national and international birdwatchers: the birdwatcher is willing to pay or not a certain amount of money per year as a contribution to reduce the net loss of wetlands and the Chinampas to zero, as a winter habitat for migratory birds in the Mexican portion of the route of the Centre.

In the case of the independent variables two criteria were selected as a basis:

1) Statistical: it was verified that the econometric model had no multicollinearity and heteroskedasticity problems. In the case of multicollinearity, it was resorted to the measure of Inflation Variance Factor (IVF); while in the case of heteroskedasticity, the Breusch-Pagan Test was used, and 2) Socioeconomic: considered other studies where bird watching is analyzed and detected economic, social and/or environmental variables that may be important in the analysis of this activity.

The variables selected to explain the dependent variable, both for national and international birdwatchers is shown in Table 2.

\subsection{Description of the Model}

A utility function is defined for the birdwatcher if they answer no to the question of WTP for the conservation of Xochimilco as a resting place for migratory birds and $\left(\mathrm{U}_{0}\right)$, and another if yes $\left(\mathrm{U}_{1}\right)$. The utility function if answers no, is shown as:

$$
\mathrm{U}_{0}(\mathrm{Y}, \mathrm{S})
$$

where $\mathrm{Y}$ is the income of the respondent and $\mathrm{S}$ are other individual characteristics such as age, sex, years of bird watching, among other variables. The utility function if the individual responds yes to the payment is represented as:

$$
\mathrm{U}_{1}(\mathrm{Y}-\mathrm{P}, \mathrm{S})
$$

where $\mathrm{P}$ is the amount of money the respondent has to pay to keep Xochimilco as a resting place for migratory birds. This method is based on the following assumptions:

- The utility has two components, one unobservable (random) and a deterministic that can be controlled.

- The probability that the birdwatcher will answer yes is:

$$
\operatorname{Prob}\left(\text { Say Yes) }=\operatorname{Prob}\left(\mathrm{U}_{1}>\mathrm{U}_{0}\right)\right.
$$

- A linear utility function is assumed with respect to income, and the rest from other characteristics of the respondent, this implies that there is no income effect. Then:

$$
\mathrm{U}_{0}(\mathrm{Y}, \mathrm{S})=\alpha_{00}+\alpha_{01} \mathrm{~S}+\beta \mathrm{Y}+\mathrm{C}_{0}
$$

where $\alpha_{00}+\alpha_{01} \mathrm{~S}+\mathrm{BY}$ is the deterministic component of the utility function and $\epsilon_{0}$ is the random component with an $\mathrm{E}\left(\mathrm{C}_{0}\right)=0$. And the utility function with change defined as: 
Table 2. Variables selected to join the model explaining the WTP for zero net loss of wetlands and Chinampas as winter habitat for migratory birds for national (Nat.) and international (Int.) birdwatchers.

\begin{tabular}{|c|c|c|c|}
\hline Model birdwatching & & Answers observers associated with the variable & Prognostic \\
\hline \multicolumn{4}{|l|}{ Dependent variable } \\
\hline $\mathrm{WTP}^{\dagger}$ & Nat. - Int. & $\begin{array}{l}\text { The project objective is to reduce to zero the net loss of wetlands and Chinampas as } \\
\text { winter habitat for migratory birds in the Mexican portion of the route of the Centre. } \\
\text { If asked, what would be the maximum amount of money you are willing to be paid } \\
\text { as a contribution to achieving the conservation of wetlands and Chinampas, how } \\
\text { much would you pay? "X" US dollars a year? }\end{array}$ & \\
\hline \multicolumn{4}{|c|}{ Independent Variable } \\
\hline \multicolumn{4}{|c|}{ Group: Socio-Economic } \\
\hline Education ${ }^{ø}$ & Nat. & $\begin{array}{l}\text { Educational level: } \\
1 \text { = Highschool, } 2 \text { = Graduate, } 3 \text { = Post graduate. }\end{array}$ & + \\
\hline $\operatorname{Age}^{x}$ & Nat. - Int. & Number of years. &,+- \\
\hline Gender $^{\dagger}$ & Nat. - Int. & $1=$ Man and $0=$ Woman. &,+- \\
\hline Income $^{\varnothing}$ & Nat. - Int. & $\begin{array}{l}\text { The range where their income. } \\
31 \text { ranges are available and ranges from lowest to highest value. }\end{array}$ & + \\
\hline \multicolumn{4}{|c|}{ Group: Birdwatching } \\
\hline Members ${ }^{*}$ & Nat. & How many members of you family are birdwatchers too? &,+- \\
\hline Eguinment & Nat - Int & Which of the following bundles best describe the gear you use for birdwatching? & \multirow{3}{*}{+} \\
\hline & & Range of five categories, from lowest to highest quality team. & \\
\hline Belongs $^{\dagger}$ & Nat. & $\begin{array}{l}\text { Do you belong to any environmental organization (birdwatching)? } \\
\text { YES }=1 \text {, NO }=0 \text {. }\end{array}$ & \\
\hline State & Int. & $\begin{array}{l}\text { Have you ever gone birdwatching outside your state? } \\
\mathrm{YES}=1, \mathrm{NO}=0 \text {. }\end{array}$ & + \\
\hline $\operatorname{Time}^{\mathrm{Y}}$ & Int. & Approximate time in minutes in a birding. & + \\
\hline \multicolumn{4}{|c|}{ Group: Payment Aspect and of the Place } \\
\hline Posture $^{y}$ & Nat. - Int. & $\begin{array}{l}\text { Posture or payment amount birder face to make your decision. } \\
\text { There are } 16 \text { (national) and } 19 \text { (international) amounts ranging from low to high value. } \\
\text { The amount offered to the observer is done randomly. }\end{array}$ & - \\
\hline \multirow[t]{3}{*}{ Rest $^{\dagger}$} & Nat. & $\begin{array}{l}\text { Do you agree with the following statement? “The preservation/conservation of these } \\
\text { resting places strongly determinates the survival of many migrating shorebird } \\
\text { species, hence the amount of this birds to be watched". }\end{array}$ & + \\
\hline & & $\mathrm{YES}=1, \mathrm{NO}=0$ & \\
\hline & & $\begin{array}{l}\text { In your opinion: the programs for the conservation/preservation of wetland areas along } \\
\text { the Central Flyway (Xochimilco), as a resting place for migrating shorebird species, } \\
\text { should be financed and handled with: }\end{array}$ & \multirow[t]{2}{*}{,+-} \\
\hline Financed $^{\dagger}$ & Nat. - Int. & $\begin{array}{l}1=\text { A mutual fund cooperation between governments of Canada, Mexico and US. } \\
0=\text { Mexican government funds independently. }\end{array}$ & \\
\hline Xochimilco $^{\dagger}$ & Nat. & $\begin{array}{l}\text { Have you ever gone birding at Xochimilco (Mexico)? } \\
\text { YES }=1, \mathrm{NO}=0 \text {. }\end{array}$ & + \\
\hline Payment $^{\dagger}$ & Nat. - Int. & $\begin{array}{l}\text { In your opinion, what would be the best payment method? } \\
1 \text { = Charge to your credit card or online payment, } 0=\text { Other no electronically. }\end{array}$ &,+- \\
\hline Residence $^{\dagger}$ & Int. & $\begin{array}{l}\text { Location. } \\
\text { Canada }=1 \text {, United States }=0 .\end{array}$ &,+- \\
\hline
\end{tabular}




$$
\mathrm{U}_{1}(\mathrm{Y}-\mathrm{P}, \mathrm{S})=\alpha_{10}+\alpha_{11} \mathrm{~S}+\beta(\mathrm{Y}-\mathrm{P})+\mathrm{C}_{1}
$$

As mentioned above, the probability of saying yes to the payment, is given by:

$$
\begin{gathered}
\operatorname{Prob}(\text { Say Yes })=\operatorname{Prob}\left(\mathrm{U}_{1}>\mathrm{U}_{0}\right) \\
\mathrm{U}_{1}(\mathrm{Y}-\mathrm{P}, \mathrm{S})-\mathrm{U}_{0}(\mathrm{Y}, \mathrm{S})=\left(\alpha_{10}+\alpha_{11} \mathrm{~S}+\beta(\mathrm{Y}-\mathrm{P})+\mathrm{C}_{1}\right)-\left(\alpha_{00}+\alpha_{01} \mathrm{~S}+\beta \mathrm{Y}+\mathrm{C}_{0}\right) \\
\mathrm{U}_{1}(\mathrm{Y}-\mathrm{P}, \mathrm{S})-\mathrm{U}_{0}(\mathrm{Y}, \mathrm{S})=\left(\alpha_{10}-\alpha_{00}\right)+\left(\alpha_{11}-\alpha_{01}\right) \mathrm{S}-\beta \mathrm{P}+\left(\mathrm{C}_{1}-\mathrm{C}_{0}\right)
\end{gathered}
$$

Si: $\alpha_{0}=\alpha_{10}-\alpha_{00}, \quad \alpha_{1}=\alpha_{11}-\alpha_{01}$ y $€=\epsilon_{1}-\epsilon_{0}$, then:

$$
\operatorname{Prob}(\text { Say Yes })=\operatorname{Prob}\left(\alpha_{0}-\alpha_{1} \mathrm{~S}-\beta \mathrm{P}>\mathrm{C}\right)
$$

where in the term $€$ represents model errors distributed logistically, therefore:

$$
\operatorname{Prob}(\text { Say Yes })=\operatorname{Prob}\left(\alpha_{0}-\alpha_{1} \mathrm{~S}-\beta \mathrm{P}>\mathrm{C}\right)=1 /\left[1+\mathrm{e}^{-(\alpha-\beta \mathrm{P})}\right]
$$

To find the maximum willingness to pay (WTP), it is needed to:

$$
\alpha_{10}+\alpha_{11} \mathrm{~S}+\beta(\mathrm{Y}-\mathrm{WTP})+\mathrm{C}_{1}=\alpha_{00}+\alpha_{01} \mathrm{~S}+\beta \mathrm{Y}+\mathrm{C}_{0}
$$

Therefore, the expected value of the WTP will be given by:

$$
\begin{gathered}
\mathrm{E}(\mathrm{WTP})=\mathrm{E}\left[\left(\alpha_{0}+\alpha_{1} \mathrm{~S}\right) / \beta\right]+\mathrm{E}[\mathrm{E} / \beta] \\
\mathrm{E}(\mathrm{WTP})=\left(\alpha_{0}+\alpha_{1} \mathrm{~S}\right) / \beta
\end{gathered}
$$

In that spirit, two logit models are raised, one for the national birdwatchers and another for international (Canada and US). In both models, it is considered as a dependent variable if the birdwatcher is willing to pay or not a certain amount of money (posture) per year as a contribution for zero net loss of wetlands and Chinampas as winter habitat for birds migration in the Mexican portion of Center Route (YES $=1$, NO $=0$ ). The independent variables in each model are:

- National birdwatchers model:

$$
\begin{aligned}
\mathrm{WTP}_{\mathrm{NAT}}= & \mathrm{X}_{0}+\mathrm{X}_{1} * \text { POSTURE }+\mathrm{X}_{2} * \text { EDUCATION }+\mathrm{X}_{3} * \text { AGE }+\mathrm{X}_{4} * \text { GENDER } \\
& +\mathrm{X}_{5} * \text { INCOME }+\mathrm{X}_{6} * \text { MEMBERS }+\mathrm{X}_{7} * \text { EQUPMENT }+\mathrm{X}_{8} * \text { BELONGS } \\
& +\mathrm{X}_{9} * \text { REST }+\mathrm{X}_{10} * \text { FINANCED }+\mathrm{X}_{11} * \mathrm{XOCHIMILCO}+\mathrm{X}_{12} * \text { PAYMENT }+\mathrm{e}
\end{aligned}
$$

- International birdwatchers model:

$$
\begin{aligned}
\mathrm{WTP}_{\mathrm{INT}}= & \mathrm{X}_{0}+\mathrm{X}_{1} * \text { POSTURE }+\mathrm{X}_{2} * \text { AGE }+\mathrm{X}_{3} * \text { GENDER }+\mathrm{X}_{4} * \text { INCOME } \\
& +\mathrm{X}_{5} * \text { TIME }+\mathrm{X}_{6} * \text { STATE }+\mathrm{X}_{7} * \text { EQUIPMENT }+\mathrm{X}_{8} * \text { FINANCED } \\
& +\mathrm{X}_{9} * \text { PAYMENT }+\mathrm{X}_{10} * \text { RESIDENCE }+\mathrm{e}
\end{aligned}
$$

\section{Results}

Descriptive statistics of the variables for the national birdwatchers $(n=358)$ show that $71 \%$ of respondents responded positively to the value that was presented as a contribution to the conservation of wetlands and Chinampas of Xochimilco, while $(\mathrm{n}=376)$ was $46 \%$ for international observers. The average amount birdwatchers had as position or cash contribution of \$21 USD for national and \$319 for international. Both national and international birdwatchers have an average education level close to complete bachelor level university. The average age for national birdwatchers is 33, while 45 for international. The 56 and $47 \%$ of respondents are men for national and international birdwatchers respectively (Table 3).

The average income for national birdwatchers per month is of \$900 to 1000 USD, while for international is $\$ 8000$ USD. The number of family members who are also birdwatchers is greater in the case of international 
Table 3. Descriptive statistics of the variables considered in the study.

\begin{tabular}{|c|c|c|c|c|c|c|}
\hline & \multicolumn{3}{|c|}{ National } & \multicolumn{3}{|c|}{ International } \\
\hline & $\mathbf{N}$ & Mean & S.D. & $\mathbf{N}$ & Mean & S.D. \\
\hline WTP & 358 & 0.71 & 0.45 & 376 & 0.46 & 0.5 \\
\hline Posture & 358 & 20.88 & 10.9 & 376 & 319 & 163 \\
\hline Education & 358 & 2.3 & 0.56 & 376 & 2.6 & 0.65 \\
\hline Age & 358 & 33.2 & 11.14 & 376 & 44.8 & 14.27 \\
\hline Gender & 358 & 0.56 & 0.5 & 376 & 0.47 & 0.5 \\
\hline Income & 358 & 10.36 & 8.73 & 376 & 10.97 & 8.7 \\
\hline Members & 358 & 0.72 & 1.07 & 376 & 1.18 & 1.16 \\
\hline Equipment & 358 & 2.86 & 1.24 & 376 & 3.35 & 1.34 \\
\hline Belongs & 358 & 0.47 & 0.5 & 376 & 0.78 & 0.41 \\
\hline Rest & 358 & 0.96 & 0.21 & 376 & 1 & 0 \\
\hline Financed & 358 & 0.92 & 0.26 & 376 & 0.93 & 0.26 \\
\hline Xochimilco & 358 & 0.63 & 0.48 & NA & NA & NA \\
\hline Payment & 358 & 0.55 & 0.5 & 376 & 0.17 & 0.38 \\
\hline Time & 358 & 175 & 113 & 376 & 228 & 247 \\
\hline State & 358 & 0.863 & 0.344 & 376 & 0.91 & 0.29 \\
\hline Residence & NA & NA & NA & 376 & 0.21 & 0.41 \\
\hline
\end{tabular}

respondents, compared with national, showing a ratio equal to $0,6 / 1$.F or both groups of birdwatchers, field equipment is identified to be very similar, approaching $8 \times 40$ binoculars or of less range. When asked if they belong to any bird watching group, approximately $47 \%$ in the case of national and $78 \%$ for international claims to belong to one. Nearly one hundred percent of all respondents, both national and international, recognize that wetlands are a resting and feeding place for migratory birds. Similarly, over $90 \%$ of all respondents indicate that conservation programs of Mexican wetlands on the route of the Center should be funded and managed by a mutual fund where the governments of Canada, Mexico and the United States cooperate.

Approximately 63\% of national respondents report having gone at least once to Xochimilco for the activity of bird watching. Regarding the average amount of time spent by a birdwatcher on a field trip, national observers use about three hours, while international four. More than $85 \%$ of national and international observers have indicated leaving the state for the activity of bird watching. Finally, in the case of international observers, $21 \%$ are resident in Canada.

Overall, the estimated econometric models, one for the national birdwatchers (Table 4) and other for international ones (Table 5), show statistical significance at a level of $1 \%$ (Prob $>\mathrm{Xi}^{2}=0.0001$ ). According to the econometric model for national watchers, about $75 \%$ of the variables considered are statistically significant at least at $10 \%$, while in the case of international watchers, it is $90 \%$ of them; however, it is necessary to consider that even the variables that were not statistically significant in both models, they are still important economic or theoretically. These are: Rest, Xochimilco and Payment. They are considered in the model, as they are relevant both from an economic and socio-environmental points of view, because they help to understand, as the other variables, the decision of birdwatchers on the willingness to pay to conserve wetlands and Chinampas of Xochimilco as a resting place for migratory birds.

The signs of the independent variables showed in Table 2 are as expected. In the case of the variables of the Socio-Economic Group for the national birdwatchers, the results indicate that: 1 ) if the educational level of the respondent increases from high school to college and college graduate, it will be $8 \%$ more likely to be willing to pay for the conservation of wetlands and Chinampas of Xochimilco as resting and feeding place for migratory 
Table 4. Econometric model results-national birdwatchers.

\begin{tabular}{|c|c|c|c|c|c|c|c|}
\hline Log likelihood & & -181.339 & & & & Obs. & 358 \\
\hline \multicolumn{2}{|c|}{ Marginal effects after logit } & 0.754 & & & & 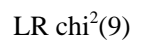 & 66.98 \\
\hline \multirow[t]{2}{*}{$\mathrm{Y}$} & $\operatorname{Pr}\left(\mathrm{WTP}_{\mathrm{NAT}}\right)$ & & & & & Prob $>\mathrm{Xi}^{2}$ & 0 \\
\hline & & & & & & Pseudo $\mathrm{R}^{2}$ & 0.1559 \\
\hline Variable & $\mathrm{dy} / \mathrm{dx}$ & Std. Err. & $\mathrm{Z}$ & $\mathrm{P}>|\mathrm{z}|$ & {$[95 \%$} & C.I] & $\mathrm{X}$ \\
\hline Education & 0.081 & 0.049 & 1.67 & $0.09 *$ & -0.014 & 0.177 & 2.307 \\
\hline Age & -0.011 & 0.003 & -3.81 & $0.00 * * *$ & -0.016 & -0.005 & 33.198 \\
\hline Gender $^{\dagger}$ & -0.151 & 0.047 & -3.17 & $0.00^{* * *}$ & -0.244 & -0.057 & 0.555 \\
\hline Income & 0.013 & 0.004 & 3.23 & $0.00^{* * *}$ & 0.005 & 0.021 & 10.361 \\
\hline Members & 0.058 & 0.029 & 1.95 & $0.05^{* *}$ & -0.001 & 0.116 & 0.723 \\
\hline Equipment & 0.039 & 0.022 & 1.74 & $0.08^{*}$ & -0.005 & 0.083 & 2.866 \\
\hline Belongs $^{\dagger}$ & -0.207 & 0.055 & -3.76 & $0.00^{* * *}$ & -0.315 & -0.099 & 0.466 \\
\hline Posture & -0.001 & 0.001 & -3.45 & $0.00^{* * *}$ & -0.001 & -0.002 & 271.397 \\
\hline Rest $^{\dagger}$ & 0.142 & 0.146 & 0.97 & 0.33 & -0.145 & 0.429 & 0.955 \\
\hline Financed $^{\dagger}$ & 0.166 & 0.111 & 1.5 & $0.10^{*}$ & -0.051 & 0.384 & 0.924 \\
\hline Xochimilco $^{\dagger}$ & 0.044 & 0.052 & 0.84 & 0.4 & -0.059 & 0.147 & 0.634 \\
\hline Payment $^{\dagger}$ & 0.058 & 0.05 & 1.15 & 0.25 & -0.041 & 0.158 & 0.553 \\
\hline
\end{tabular}

Table 5. Econometric model results-international birdwatchers.

\begin{tabular}{|c|c|c|c|c|c|c|c|}
\hline Log likelihoo & & -232.935 & & & & Obs. & 376 \\
\hline \multicolumn{2}{|c|}{ Marginal effects after logit } & 0.451 & & & & $\operatorname{LR} \operatorname{chi}^{2}(9)$ & 52.65 \\
\hline \multirow[t]{2}{*}{$\mathrm{Y}$} & $\operatorname{Pr}\left(\mathrm{WTP}_{\mathrm{INT}}\right)$ & & & & & Prob $>\mathrm{Xi}^{2}$ & 0 \\
\hline & & & & & & Pseudo $\mathrm{R}^{2}$ & 0.1015 \\
\hline Variable & $\mathrm{dy} / \mathrm{dx}$ & Std. Err. & $\mathrm{Z}$ & $\mathrm{P}>|\mathrm{z}|$ & {$[95 \%$} & C.I] & $\mathrm{X}$ \\
\hline Age & -0.006 & 0.002 & -2.86 & $0.004 * * *$ & -0.01 & -0.002 & 44.803 \\
\hline Gender† & -0.118 & 0.056 & -2.1 & $0.035^{* * *}$ & -0.228 & -0.008 & 0.465 \\
\hline Income & 0.006 & 0.003 & 1.83 & $0.067 * *$ & -0.001 & 0.013 & 10.979 \\
\hline Time & 0.001 & 0.001 & 2.33 & $0.020 * * *$ & 0.001 & 0.002 & 228.537 \\
\hline Equipment & -0.049 & 0.023 & -2.08 & $0.037 * * *$ & -0.094 & -0.003 & 3.346 \\
\hline State $^{\dagger}$ & 0.191 & 0.091 & 2.1 & $0.036 * *$ & 0.012 & 0.369 & 0.912 \\
\hline Posture & -0.001 & 0 & -3.54 & $0.000 * * *$ & -0.001 & -0.001 & 319.947 \\
\hline Residence $^{\dagger}$ & 0.156 & 0.069 & 2.24 & $0.025^{* * *}$ & 0.019 & 0.292 & 0.207 \\
\hline Financed $^{\dagger}$ & 0.257 & 0.084 & 3.02 & $0.003^{* * *}$ & 0.091 & 0.423 & 0.925 \\
\hline Payment $^{\dagger}$ & 0.081 & 0.073 & 1.1 & 0.269 & -0.063 & 0.224 & 0.173 \\
\hline
\end{tabular}


birds; 2) as the birdwatcher is one year older, the probability to agree to do the payment is reduced by $1.1 \%$; 3 ) if the watcher is female, the probability of availability to pay increases by $15 \%$, and 4) finally, for each additional range that increases the income of the national watcher, the probability to pay for conservation of wetlands increases by $1.3 \%$.

The group of bird watching variables for national ones shows the highest average contribution by variables to explain the dependent variable. For each variable that conforms this group, we find that: 1) as it increases by a person the birdwatchers at home, a chance to be willing to accept the amount of WTP increases by 5.8\%; 2) on the other hand, it is observed that the more quality the equipment has to make the observation, the probability of accepting the WTP increases by 3.9\%; and 3) finally, if the national respondent belongs to a group or birding club, the probability of accepting the payment is reduced by $20 \%$.

In the case of the variable group of Payment Aspect and of the Place, it is observed that: 1) with increasing the amount or posture (Mexican pesos) facing the respondent to decide whether or not to pay for the conservation of wetlands, the probability to accept is reduced by $0.1 \%$, provided to certain extent the law of demand; 2 ) when the national watchers have the knowledge that wetlands of Xochimilco are rest areas for migratory birds, the probability to accept payment for the conservation of these increases by $14 \%$; 3 ) when the national birdwatchers are certain that if the conservation program of Xochimilco wetlands would be financed and managed by a mutual fund between the governments of Canada, Mexico and the United States, the probability to accept the WTP increases by $16.6 \%$; 4) the fact that the national birdwatchers already know Xochimilco wetlands, causes the probability of accepting the position or pay to increase by $4.4 \%$; and finally; 5 ) if the payment can be made by online or charged to a credit card, the probability of accepting payment increases by $5.8 \%$.

In the case of the econometric model of the international birdwatchers, all groups have one or two variables that have the highest weight among all. For the Socioeconomic group, we see that 1) if the respondent's age increases by one year older, the chance to say no payment is reduced by one percent; 2) if the birdwatcher is man, the probability is reduced by $11 \%$; and 3 ) if the range of income increases, the probability of saying yes to pay for the conservation of wetlands and Chinampas of Xochimilco is increased by $0.1 \%$.

In the Bird watching group 1) the variable with the highest weight is the state, which means, whether international birdwatchers have performed this activity out of their state where they live, the probability of accepting the amount allocated for the conservation of wetlands increases by 19\%; 2) the following variable with the highest weight in this group is the equipment, therefore, as it increases the quality of it the probability of accepting payment decreases by $4.9 \%$ and finally; 3 ) with increasing time to an hour of birding, the probability of payment increases by $6 \%$.

In the case of the third group of variables, Payment aspect and Place, it is shown that 1) if the payment amount or posture increases by ten dollars, the probability of accepting is reduced by $1 \%$; 2 ) if the birdwatcher lives in Canada, the probability of accepting the payment is increased by $15.6 \%$; 3 ) if international birdwatchers have the knowledge that the program for the conservation of wetlands in Xochimilco will be held by a mutual fund and management by the governments of Mexico, USA and Canada, the probability increases by 25\%; and finally 4) if the payment is made electronically, the probability of accepting the payment is increased by $8 \%$.

Finally, these marginal effects found for the proposed econometric models, allow to calculate the willingness to pay (WTP) of the birder watcher yearly, both national and international ones, to achieve the conservation of wetlands and Chinampas of Xochimilco as a resting and feeding for migratory birds traveling the route of the Centre (from North America to Central and South America). By replacing these effects in formula 13, it is estimated that the WTP per year of national watchers is approximately equal to US \$79.7; while in the case of international watchers, the annual WTP is approximately equal to \$296 USD.

\section{Discussion}

Bird watching is an ecotourism activity that reports a great economic benefit to countries like the US or Canada [1]. In the first case, it is estimated that by the year 2006, the apportionment was approximately of $\$ 35.700$ million US dollars, generated by 48 million of watchers that exist in that country [2]. In the case of Mexico, this activity has great economic potential due to the bird population of the country represents eleven percent of all birds of the world, and from this percentage, ten percent are endemic species. Furthermore, it is estimated that from those 48 million of birdwatchers that exist in the United States, about $20 \%$ are people doing bird watching outside their country [2] taking into account that $40 \%$ of the species in Mexico are not shared with the United 
States [11], more than half of migratory species come from North America spend between six and eight months in Mexico and proximity, position Mexico as a desirable place for birding to American people.

An important place in Mexico for bird watching, is the wetlands of Mexico City and surrounding areas; which, in addition to presenting a variety of local birds are resting places, food and/or shelter for migratory birds coming from North America through the route of the Center [11] [12]. Within these important wetlands, there is the Ejido de Xochimilco and San Gregorio Atlapulco, which besides being a RAMSAR site and a Protected Natural Area is part of the UNESCO recognition as a Cultural and Natural World Heritage, for the presence of Chinampas, which are highly productive prehispanic, agricultural systems. Furthermore, the Ejido de Xochimilco and San Gregorio Atlapulco and other adjacent urban wetlands, suffer constantly growing pressure for urban sprawl, chemical pollutants from agricultural greenhouses, irregular settlements, direct discharges of household waste, among others [16]. In that sense, an approximation of the economic value of environmental goods and services offered by the protected area, in this case the bird population through birdwatching, is very important to demonstrate the biological and economic importance conservation of this place and the development of public policy.

The estimate of the willingness to pay of both national and international ones, \$79.7 and \$296 usd per year respectively, allows watchers to estimate the economic value about this ecotouristic activity in Xochimilco. To this purpose, we assume that only ten percent of the 9.8 million American birdwatchers travel to Mexico for this activity, and that in Mexico there are about 20 thousand national birdwatchers. With this conservative assumption, in Table 6 it is analyzed the sensitivity of the WTP for different percentages of birdwatchers who would be willing to pay. According to Cantu et al. [2], for 2006 nationwide there were 78,000 registered between national and international birdwatchers that data allows to have an upper limit for the analysis. For example, if three percent of national and international watchers would be willing to pay the calculated amount (38\% of the observers registered in 2006), the economic value per year for watching migratory birds in the Natural Protected Area of Ejido Xochimilco and San Gregorio Atlapulco would be approximately equal to 8.7 million US dollars a year, about \$3293 per hectare. This value may change, but it will depend on both the number of observers arriving in Mexico, observers who come to perform that activity in Xochimilco and/or the percentage of birdwatchers who are willing to pay. However, an average for this value can be taken, considering a maximum 78 thousand watchers recorded in 2006, obtaining a value between 2836 and 3999 US dollars per hectare.

This estimate, between 2836 and 3999 US dollars per hectare, allows a partial approximation of the economic value of environmental services provided by Xochimilco to the inhabitants Mexico City, and that can serve as a parameter to discuss with the authorities and/or designers of public policy on the future of this urban wetland.

Furthermore, it is interesting that different socio-economic variables, of the local environment and/or related to the activity can positively or negatively affect the decision to accept or not a willingness to pay by the birdwatchers. These effects should be considered by designers of public policy or projects, in this case in Xochimilco with bird watching, for best results. In the case of the socioeconomic variables, the age has an inverse

Table 6. Sensitivity analysis of the WTP for national and international birdwatchers.

\begin{tabular}{ccccccccccc}
\hline & \multicolumn{3}{c}{ National (20000 Obs.)* } & \multicolumn{3}{c}{ International (980.000)* } & \multicolumn{3}{c}{ OVERALL } \\
\hline \%** & Obs. & US dollars & Dollars/Hect. & Obs. & US dollars & Dollars/Hect. & Obs. & US dollars & Dollars/Hect. \\
\hline $0.50 \%$ & 100 & 7970 & 3 & 4900 & $1,450,400$ & 546 & 5000 & $1,458,370$ & 549 \\
$1 \%$ & 200 & 15,941 & 6 & 9800 & $2,900,800$ & 1092 & 10,000 & $2,916,741$ & 1098 \\
$2 \%$ & 400 & 31,881 & 12 & 19,600 & $5,801,600$ & 2184 & 20,000 & $5,833,481$ & 2196 \\
$3 \%$ & 600 & 47,822 & 18 & 29,400 & $8,702,400$ & 3275 & 30,000 & $8,750,222$ & 3293 \\
$4 \%$ & 800 & 63,763 & 24 & 39,200 & $11,603,200$ & 4367 & 40,000 & $11,666,963$ & 4391 \\
$5 \%$ & 1000 & 79,704 & 30 & 49,000 & $14,504,000$ & 5459 & 50,000 & $14,583,704$ & 5489 \\
$10 \%$ & 2000 & 159,407 & 60 & 98,000 & $29,008,000$ & 10,918 & 100,000 & $29,167,407$ & 10,978 \\
$15 \%$ & 3000 & 239,111 & 90 & 147,000 & $43,512,000$ & 16,376 & 150,000 & $43,751,111$ & 16,466 \\
\hline
\end{tabular}

*Potential national and international birdwatchers that could perform such activity in Mexico; **Percentage of national and international birdwatchers who could be willing to pay for such activity in Xochimilco, Mexico. 
relationship to the probability of accepting the WTP [18] [19] [33]. That means, the older the age, the lower the probability that the birdwatchers are willing to make a payment to achieve wetland conservation. This may have two explanations, 1) on the understanding that younger people have greater awareness to achieve conservation of Xochimilco as a resting place for migrating birds than older people [19] and/or 2) that older people with more experience of the changes occurred in Xochimilco, notice that the place is losing conditions for the activity compared to younger people, known as the syndrome of changing base [19]. As Brouwer \& van Beukering Sultanian [17] and Wilson \& Tisdell [34] a direct relationship is evident between the acceptance of the WTP and the educational level of the respondent. It is necessary to point out that all respondents are birdwatchers, therefore the higher the educational knowledge and/or higher knowledge about nature, it is expected to be more likely to accept the payment for achieving conservation of any place that offers environmental services to society [18]. In the case of the variable of income, it is observed a direct relationship with respect to the WTP [17] [35]-[37]. This means, higher levels of income, more likely to accept a payment. This variable behaves as established in economic theory, specifically in determining the demand for a normal good. Finally, among the variables considered in the socio-economic group, gender is the one with the heaviest weight or impact about accepting or not a WTP to achieve this urban wetland conservation. For both national and international birdwatchers, being a woman is more likely to want to accept payment and thus achieve the conservation of Xochimilco as a resting place and/or migratory bird refuge [18] [36]. According to studies on gender and natural resources, this can be explained because women have a higher calling and a greater instinct for achieving conservation of resources relative to men, in order to leave something for the future for either consumption or enjoyment of this or the next generation.

Regarding the second group considered in this study, variables related to the activity of bird watching, the variable with the greatest impact with respect to the WTP is whether birdwatcher belongs in a group that performs this activity. In this case, the relationship is reversed, meaning that if a person belongs to a group, it can be assumed that the membership or other fees that may be associated with are already being paid for performing the observation or preservation of the sites. Two important variables in the activity of bird watching is the number of family members that perform the activity and the time spent at a field trip, in both cases the relationship is direct with respect to the WTP [35] [38]. That is, families with a higher number of watchers and that spend more time birding, are more likely to accept a payment and therefore to have major considerations for urban wetlands, such as Xochimilco, to be preserved. Finally, a very important variable for the case of Xochimilco and/or wetlands that are outside of the United States and/or Canada, and offer environmental services as resting place for migratory birds is referred to the probability of accepting payment for birdwatchers who leave their state to perform this activity. This means, those birder watchers who usually leave their home state for bird watching, are more willing to make a payment for the preservation of these places. Therefore, in the case of birdwatchers who come to Mexico and especially to urban wetlands of Mexico City and its neighboring areas, presents a potential market for the benefit of developing a national and international conservation ecotourism activity, that could generate significant income and higher levels of welfare for society [36] [39].

In the case of the third group, variables related to the place of birding, the variable with the greatest weight to determine if birdwatchers are willing to pay or not is who should fund and who should manage the conservation program. This variable is important to the extent that birdwatchers can identify who are the beneficiaries of this ecosystem service are, and therefore who should be responsible for its care. In this case, both national and international observers point as the best option that a conservation program of Xochimilco as a resting place for migratory birds should be funded and managed by a mutual fund between the governments of Canada, Mexico and the United States as the three countries are committed to the conservation of sort of places of such biologically importance. On the other hand, to have greater knowledge of these wetlands about their importance in the migration routes of birds [17] [34] [37] and/or to have already been there [36], allows to have a bigger possibility that birdwatchers would be more willing to pay to achieve their conservation; in that sense, the importance of showing to the society that wetlands provide environmental goods and services for the benefit of all, and for this reason they should be considered and preserved.

\section{Conclusions}

The Lakeside System of Ejidos de Xochimilco and San Gregorio Atlapulco located in the center-east of the Federal District of Mexico is one part of the last remaining urban wetlands mainly due to the invasion of urban 
sprawl, sewage discharge, establishment of greenhouses for production of vegetables and flowers with agrochemicals at the expense of traditional Chinampería and the ignorance by the population of the importance of environmental goods and services provided to society [16]. The main environmental goods and services offered by this Protected Area, RAMSAR site and Natural and Cultural World Heritage (UNESCO) have a plethora of flora and fauna both aquatic and terrestrial, carbon sequestration, infiltration and purification of water, scenic beauty, endemic species such as the Axolote (Ambystoma mexicanum), and important place for migratory birds arriving from North America, among others.

In the case of migrating birds, it estimates arrival of about 90 species, mainly in the winter from Canada and the United States through the Route of the Center, seeking rest, food and reproduction. The main migratory birds that come to the place are the white pelican (Pelecanus erythororhynchos), the olive cormorant (Phalacrocorax auritus), several gulls and terns [13] [14]. In that sense, Xochimilco and other urban wetlands that remain around are of great importance for bird conservation. Therefore, awareness of this environmental service or non-existence of a formal market for this type of service does not mean that it does not have value or benefit to the society. Trying to economically evaluate this type of environmental goods and services offers more management tools for decision makers when facing the decision to keep urban wetlands or not against development of other ideas or projects such as the case of real estate developments, construction of infrastructure such as roads and bridges, among others.

The estimate of the willingness to pay (WTP) of approximately US \$80 and \$296 per year respectively for national and international watchers allows capturing that value in economic terms that people have to keep Xochimilco as a resting place for migratory birds. Moreover, these estimated individual values of the WTP allow calculating the economic value that society as a whole, in this case birdwatchers, presents for this environmental service that is approximately between US \$2836 and \$3999 per hectare. This calculation, as indicated above, can be used for decision making between two or more projects that are willing to work in the Lakeside System of Ejidos de Xochimilco and San Gregorio Atlapulco, and that in most cases it can go in opposite directions. However, it is necessary to indicate that this range calculated per hectare corresponds only to one of the most important environmental services provided by this urban wetland; it would be interesting to complement it with other services and environmental goods.

Having the estimate of economic value and the importance to society as a whole of this type of urban wetland, it can be considered to develop some ecotouristic activities focused on birdwatching and other goods and/or environmental services, in addition to help conserve the site and species of birds that live there [20], which would allow important and/or additional income for the benefit of people living in the Protected Natural Area near to it or the general society, so it happens in the United States and Canada [39]. Complementing this, it is necessary for project developers or people involved in ecotourism to take into account that variables such as income level, gender, age, educational level, form of payment, and time that a person performs birdwatching, among others can positively or negatively affect the potential birdwatchers to be willing or not to visit the site and/or pay something for performing such activity.

Finally, it is important to show people that this kind of urban wetlands is not public space areas and they do not provide any kind of benefit to society; on the contrary, it must show and raise awareness that these are spaces providing limited environment, economic and culture goods and services for the benefit of all of us. And if they have no market, which does not mean they have no value, therefore they must not be preserved or less considered within the public policies' planning and development.

\section{Acknowledgements}

This study was funded through the Postdoctoral Fellowship Program at the National Autonomous University of Mexico 2013-I (UNAM), through the project of Economic valuation of ecosystem services that offers the lake system of Xochimilco, Mexico City, Mexico.

Thanks to Margarita Velázquez Gutierrez, director of the Regional Center for Multidisciplinary Investigations (CRIM-UNAM) and all the staff of that institution for their logistical support. Similarly, to Raul Garcia Barrios and Alonso Aguilar for academic advice. To Elsa Valiente and all the staff of Restauración Ecologica y Desarrollo A.C. for its support on the field. To Velu Ochoa of the International Alliances Program of the National Audubon Society, to Jose Rafael Calderon and Ruben Ortega Alvarez of NABCI-CONABIO, Aves FC-UNAM and to Bird Canada for helping circulate the surveys. And especially to everyone who offered a few minutes of their time to complete them. 


\section{References}

[1] US Fish \& Wildlife Service (2013) Birding in the United States: A Demographic and Economic Analysis. Addendum to the 2011 National Survey of Fishing, Hunting, and Wildlife-Associated Recreation. Report 2011-1, Division of Economics, Arlington.

[2] Cantú, J.C. and Sánchez, M.E. (2011) Observación de aves: Industria millonaria. CONABIO. Biodiversitas, 97, 10-15.

[3] Llorente-Bousquets, J. and Ocegueda, S. (2008) Estado del conocimiento de la biota, en Capital natural de México, vol. I: Conocimiento actual de la biodiversidad. Conabio, México, 283-322.

[4] Navarro, A.G., Rebón, M.F., Gordillo, A., Peterson, T., Berlanga, H. and Sánchez, L. (2014) Biodiversidad de las aves en México. Revista Mexicana de la Biodiversidad, 85, 476-495.

[5] Berlanga, H., Rodríguez-Contreras, V., Oliveras de Ita, A., Escobar, M., Rodríguez, L., Vieyra, J. and Vargas, V. (2008) Red de Conocimiento sobre las Aves de México (AVESMX). CONABIO.

[6] Navarro, S.A. and Gordillo, A. (2006) Catálogo de autoridad taxonómica de la avifauna de México. Museo de Zoología, Facultad de Ciencias, UNAM. Base de datos snib-CONABIO, proyecto CS010.

[7] Newton, I. (2008) The Migration Ecology of Birds. Academic Press, Waltham, Massachusetts.

[8] Rich, T.D., Beardmore, C.J., Berlanga, H., Blancher, P.J., Bradstreet, M.S.W., Butcher, G.S., Demarest, D.W., Dunn, E.H., Hunter, W.C., Iñigo-Elias, E.E., Kennedy, J.A., Martell, A.M., Panjabi, A.O., Pashley, D.N., Rosenberg, K.V., Rustay, C.M., Wendt, J.S. and Will, T.C. (2004) Partners in Flight: North American Landbird Conservation Plan. Cornell Lab of Ornithology, Ithaca.

[9] UNEP/CMS (2009) A Bird's Eye View on Flyways: A Brief Tour by the Convention on the Conservation of Migratory Species of Wild Animals. UNEP/CMS Secretariat, Bonn.

[10] Berlanga, H. and Rodríguez, V. (SF) Las aves migratorias: A prueba de muros. Iniciativa para la conservación de las aves de América del Norte. CONABIO.

[11] de Silva, H.G., Grosselet, M., Meléndez, A.H. and Wilson, R.G. (2006) Records of Sternini from the Valley of México. Cotinga, 26, 60-62.

[12] Calderón, J.R. (2011) Distribución y uso de hábitat de la avifauna en La Ciénega Grande de Xochimilco y su utilidad para educación ambiental. Tesis para obtener el grado de Maestro en Biología. Universidad Autónoma Metropolitana, México.

[13] Ramírez-Bastida, P., Varona-Graniel, D.E. and de Sucre-Medrano, A.E. (2011) Aves en los relictos de un gran lago: Los humedales de la Ciudad de México y áreas vecinas. El Canto del Centzontle, 2, 72-86.

[14] Hernández, C.A. and Meléndez, A.H. (1985) La riqueza de aves de Xochimilco. Universidad Autónoma Metropolitana, División Ciencias Biológicas y Salud, México, D.F.

[15] GDF (2006) Programa de Manejo del Área Natural Protegida con carácter de Zona de Conservación Ecológica “Ejidos de Xochimilco y San Gregorio Atlapulco”. Gaceta Oficial del Distrito Federal, Ciudad de México, México, 164.

[16] Aguilar, A.G. (2008) Peri-Urbanization, Illegal Settlements and Environmental Impact in Mexico City. Cities, 25, 133145. http://dx.doi.org/10.1016/j.cities.2008.02.003

[17] Brouwer, R., van Beukering, P. and Sultanian, E. (2008) The Impact of the Bird Flu on Public Willingness to Pay for the Protection of Migratory Birds. Ecological Economics, 64, 575-585. http://dx.doi.org/10.1016/j.ecolecon.2007.04.001

[18] Stevens, T.H., Echeverria, J., Glass, R.J., Hager, T. and More, T.A. (1991) Measuring the Existence Value of Wildlife: What Do CVM Estimates Really Show? Land Economics, 67, 390-400. http://dx.doi.org/10.2307/3146546

[19] Ojea, E. and Loureiro, M.L. (2007) Altruistic, Egoistic and Biospheric Values in Willingness to Pay (WTP) for Wildlife. Ecological Economics, 63, 807-814. http://dx.doi.org/10.1016/j.ecolecon.2007.02.003

[20] Stoll, J.R., Ditton, R.B. and Eubanks, T.L. (2006) Platte River Birding and the Spring Migration: Hummans, Value, and Unique Ecological Resources. Human Dimensions of Wildlife, 11, 241-254. http://dx.doi.org/10.1080/10871200600802939

[21] Menkhaus, S. and Lober, D.J. (1996) International Ecoturism and the Valuation of Tropical Rainforests in Costa Rica. Journal of Environmental Management, 47, 1-10. http://dx.doi.org/10.1006/jema.1996.0031

[22] Kellermann, J.L., Johnson, M.D., Stercho, A.M. and Hackett, S.C. (2008) Ecological and Economic Services Provided by Birds on Jamaica Blue Mountain Coffee Farms. Conservation Biology, 22, 1177-1185.

[23] Naidoo, R. and Adamowicz, W. (2005) Economic Benefits of Biodiversity Exceed Costs of Conservation at an African Rainforest Reserve. Proceedings of the National Academy of Sciences of the United States of America, 102, 1671216716. http://dx.doi.org/10.1073/pnas.0508036102

[24] Boyle, K.J. and Bishop, R. (1987) Valuing Wildlife in Benefit-Cost Analyses: A Case Study Involving Endangered 
Species. Water Resources Research, 23, 943-950. http://dx.doi.org/10.1029/WR023i005p00943

[25] Sultatian, E. and Van Beukering, P.J.H. (2007) Economics of Migratory Birds. Poverty Reduction and Environmental Management. Working Paper.

[26] Boyle, K.J., Johnson, R., McCollum, D.W., Desvousges, W.H., Dunford, R. and Hundson, S. (1994) An Investigation of Part-Whole Biases in Contingent Valuation Studies. Journal of Environmental Economics and Management, 27, 6483. http://dx.doi.org/10.1006/jeem.1994.1026

[27] Rubin, J., Helfand, G. and Loomis, J. (1991) A Benefit-Cost Analysis of the Northern Spotted Owl. Journal of Forestry, 12, 25-30.

[28] Navrud, S. and Mungatana, E.D. (1994) Environmental Valuation in Developing Countries: The Recreational Value of Wildlife Viewing. Ecological Economics, 11, 135-151. http://dx.doi.org/10.1016/0921-8009(94)90024-8

[29] Clark, W.R. (1987) Economics and Marketing of “Canada’s Capistrano”. In: Diamond and Filion, Eds., The Value of Birds, International Council for Bird Preservation Technical Publication 6, 31-48.

[30] Merlín-Uribe, Y., Contreras-Hernández, A., Astier-Calderón, M., Jensen, O.P., Zaragoza, R. and Zambrano, L. (2013) Urban Expansion into a Protected Natural Area in Mexico City: Alternative Management Scenarios. Journal of Environmental Planning and Management, 56, 398-411. http://dx.doi.org/10.1080/09640568.2012.683686

[31] Wigle, J. (2010) The “Xochimilco Model” for Managing Irregular Settlements in Conservation Land in Mexico. Cities, 27, 337-347. http://dx.doi.org/10.1016/j.cities.2010.04.003

[32] Merlín-Uribe, Y., González-Esquivel, C.E., Contreras-Hernández, A., Zambrano, L., Moreno-Casasola, P. and Astier, M. (2013) Environmental and Socio-Economic Sustainability of Chinampas (Raised Beds) in Xochimilco, Mexico City. International Journal of Agricultural Sustainability, 11, 216-233. http://dx.doi.org/10.1080/14735903.2012.726128

[33] Loomis, J.B. and González-Cabán, A. (1998) A Willingness-to-Pay Function for Protecting Acres of Spotted Owl Habitat from Fire. Ecological Economics, 25, 315-322. http://dx.doi.org/10.1016/S0921-8009(97)00044-X

[34] Wilson, C. and Tisdell, C. (2005) How Knowledge Affects Payment to Conserve an Endangered Bird. Working Papers on Economics, Ecology and the Environment. Working Paper No. 116. The University of Queensland.

[35] Myers, K., Parsons, G. and Edwards, P.E.T. (2010) Measuring the Recreational Use Value of Migratory Shorebirds on the Delaware Bay. Marine Resources Economics, 25, 247-264. http://dx.doi.org/10.5950/0738-1360-25.3.247

[36] Leea, C.-K., Leeb, J.-H., Kimc, T.-K. and Mjelde, J.W. (2010) Preferences and Willingness to Pay for Bird-Watching Tour and Interpretative Services Using a Choice Experiment. Journal of Sustainable Tourism, 18, 695-708. http://dx.doi.org/10.1080/09669581003602333

[37] Kotchen, M. and Reiling, S.D. (2000) Environmental Attitudes, Motivations, and Contingent Valuation of Nonuse Values: A Case Study Involving Endangered Species. Ecological Economics, 32, 93-107. http://dx.doi.org/10.1016/S0921-8009(99)00069-5

[38] Macmillan, D.C., Philip, L., Hanley, N. and Alvarez-Farizio, B. (2002) Valuing the Non-Market Benefits of Wild Goose Conservation: A Comparison of Interview and Group-Based Approaches. Ecological Economics, 43, 49-59. http://dx.doi.org/10.1016/S0921-8009(02)00182-9

[39] Hvenegaard, G.T., Butler, J.R. and Krystofiak, D.K. (1989) Economic Values of Bird Watching at Point Pelee National Park, Canada. Wildlife Society Bulletin, 17, 526-531.

[40] Kaval, P. and Roskruge, M. (2009) The Value of Native Bird Conservation: A New Zealand Case Study. Department of Economics Working Paper Series, Number 09/11. University of Waikato, Hamilton, New Zealand.

http://researchcommons.waikato.ac.nz/handle/10289/3650 
Appendix 1: Literature Review Based on Kaval \& Roskruge [40]

\begin{tabular}{|c|c|c|c|c|c|c|}
\hline Author/s & Species valued & Year & Location & Method & Frequency & Value \$US (2014) \\
\hline \multicolumn{7}{|c|}{ Individual Bird Species Valuation Study Results } \\
\hline Swanson & $\begin{array}{l}\text { Bald Eagle } \\
\text { (Haliaeetus leucocephalus) }\end{array}$ & 1993 & Washington, US & CVM & One-Time Donation & $\$ 887.70$ \\
\hline Stevens et al. & $\begin{array}{l}\text { Bald Eagle } \\
\text { (Haliaeetus leucocephalus) }\end{array}$ & 1991 & New England, US & CVM & Annually & $\$ 68.11$ \\
\hline Boyle \& Bishop & $\begin{array}{l}\text { Bald eagle } \\
\text { (Haliaeetus leucocephalus) }\end{array}$ & 1987 & Wisconsin, US & $\begin{array}{l}\text { Benefit-Cost } \\
\text { Analyses }\end{array}$ & Annually & $\$ 53.69$ \\
\hline Ojea \& Loureiro & $\begin{array}{l}\text { Common murre } \\
\text { (Uria aalge) }\end{array}$ & 2007 & Galicia, Spain & CVM & Annually & $\$ 55.55$ \\
\hline Matauschek & Corncrake (Crex crex) & 2005 & Germany & Opportunity Cost & Total Value & $\$ 1094912153.03$ \\
\hline Wilson \& Tisdell & $\begin{array}{l}\text { Golden Shouldered Parrot } \\
\text { (Psephotus chrysopterygius) }\end{array}$ & 2007 & Australia & CVM & Annually & $\$ 135.15$ \\
\hline $\begin{array}{l}\text { Navrud \& } \\
\text { Mungatana }\end{array}$ & $\begin{array}{l}\text { Lesser \& Greater } \\
\text { Flamingos } \\
\text { (Phoenicopterus minor } \\
\text { and roseus) }\end{array}$ & 1994 & $\begin{array}{l}\text { Lake Nakuru } \\
\text { N.P., Kenya }\end{array}$ & $\begin{array}{l}\text { Travel-Cost, } \\
\text { CVM }\end{array}$ & Per Visit & $\$ 73.52$ \\
\hline $\begin{array}{l}\text { Loomis \& } \\
\text { Ekstrand }\end{array}$ & $\begin{array}{l}\text { Mexican Spotted } \\
\text { Owl \& Habitat } \\
\text { (Strix occidentalis) }\end{array}$ & 1997 & US & CVM & Annually & $\$ 105.73$ \\
\hline Rubin et al. & $\begin{array}{l}\text { Northern Spotted Owl } \\
\text { (Strix occidentalis) }\end{array}$ & 1991 & $\begin{array}{l}\text { Washington } \\
\text { State, US }\end{array}$ & $\begin{array}{l}\text { Benefit-cost } \\
\text { Analyses }\end{array}$ & Annually & $\$ 138.85$ \\
\hline $\begin{array}{l}\text { Kotchen \& } \\
\text { Reiling }\end{array}$ & $\begin{array}{l}\text { Peregrine Falcon } \\
\text { (Falco peregrinus) }\end{array}$ & 2000 & Maine US & CVM & Annually & $\$ 83.38$ \\
\hline Reaves et al. & $\begin{array}{l}\text { Red Cockaded Woodpecker } \\
\text { (Picoides borealis) }\end{array}$ & 1999 & $\begin{array}{l}\text { South Carolina } \\
\text { \& US }\end{array}$ & CVM & Annually & $\$ 21.05$ \\
\hline Christie & Red Kite (Milvus milvus) & 2007 & United Kingdom & CVM & One-Time donation & $\$ 19.02$ \\
\hline MacMillian et al. & Red Kite (Milvus milvus) & 2006 & Scotland & CVM & Annually & $\$ 31.68$ \\
\hline Fahy \& Kerr. & $\begin{array}{l}\text { Royal Albatross } \\
\text { (Diomedea epomophora) }\end{array}$ & 1991 & New Zealand & CVM & Annually & $\$ 42.54$ \\
\hline Hagen et al. & $\begin{array}{l}\text { Spotted Owl } \\
\text { (Strix occidentalis) }\end{array}$ & 1992 & US & CVM & Annually & $\$ 247.65$ \\
\hline $\begin{array}{l}\text { Loomis \& } \\
\text { González-Cabán }\end{array}$ & $\begin{array}{l}\text { Spotted Owl habitat } \\
\text { (Strix occidentalis) }\end{array}$ & 1998 & $\begin{array}{l}\text { California \& } \\
\text { New England }\end{array}$ & CVM & Annually & $\$ 142.25$ \\
\hline Bowker \& Stoll & $\begin{array}{l}\text { Whooping Crane } \\
\text { (Grus americana) }\end{array}$ & 1988 & $\begin{array}{c}\text { Texas (Residents) } \\
\text { US }\end{array}$ & CVM & Annually & $\$ 232.98$ \\
\hline Stoll \& Johnson & $\begin{array}{l}\text { Whooping Crane } \\
\text { (Grus americana) }\end{array}$ & 1984 & Texas \& US & CVM & Not reported & Not Reported \\
\hline Macmillian et al. & $\begin{array}{l}\text { Wild Geese } \\
\text { (Anser cygnoides) }\end{array}$ & 2002 & Scotland & CVM & One-Time Donation & $\$ 82.90$ \\
\hline Stevens et al. & $\begin{array}{l}\text { Wild Turkey } \\
\text { (Meleagris gallopavo) }\end{array}$ & 1991 & $\begin{array}{l}\text { New England, } \\
\text { US }\end{array}$ & CVM & Annually & $\$ 41.89$ \\
\hline Wilson \& Tisdell & $\begin{array}{l}\text { Southern Cassowary } \\
\text { (Cauarius casuarius) }\end{array}$ & 2005 & Australia & Survey & Annually & $\$ 18.8 / \$ 1000$ \\
\hline Wilson \& Tisdell & Brolga (Grus rubicunda) & 2005 & Australia & Survey & Annually & $\$ 13.1 / \$ 1000$ \\
\hline Wilson \& Tisdell & $\begin{array}{l}\text { Laughing Kookaburra } \\
\text { (Dacelo novaeguineae) }\end{array}$ & 2005 & Australia & Survey & Annually & $\$ 7.2 / \$ 1000$ \\
\hline Wilson \& Tisdell & $\begin{array}{l}\text { Australian Magpie } \\
\text { (Cracticus tibicen) }\end{array}$ & 2005 & Australia & Survey & Annually & $\$ 5.1 / \$ 1000$ \\
\hline Wilson \& Tisdell & $\begin{array}{l}\text { Red-tailed Black Cockatoo } \\
\text { (Calyptorhynchus banksii) }\end{array}$ & 2005 & Australia & Survey & Annually & $\$ 8.2 / \$ 1000$ \\
\hline
\end{tabular}




\section{Continued}

\begin{tabular}{clllllr}
\hline Wilson \& Tisdell & $\begin{array}{l}\text { Palm Cockatoo } \\
\text { (Probosciger aterrimus) }\end{array}$ & 2005 & Australia & Survey & Annually & $\$ 9.4 / \$ 1000$ \\
Wilson \& Tisdell & $\begin{array}{l}\text { Eclectus Parrot } \\
\text { (Eclectus roratus) }\end{array}$ & 2005 & Australia & Survey & Annually & $\$ 11.1 / \$ 1000$ \\
Wilson \& Tisdell & $\begin{array}{l}\text { Golden Bowerbird } \\
\text { (Prinodura newtoniana) }\end{array}$ & 2005 & Australia & Survey & Annually & $\$ 10.3 / \$ 1000$ \\
Wilson \& Tisdell & $\begin{array}{l}\text { Golden-Shouldered Parrot } \\
\text { (Psephotus chrysopterygius) }\end{array}$ & 2005 & Australia & Survey & Annually & $\$ .18 .6 / \$ 1000$ \\
Wilson \& Tisdell & $\begin{array}{l}\text { Gouldian Finch } \\
\text { (Erythrura gouldiae) }\end{array}$ & 2005 & Australia & Survey & Annually & $\$ 20.5 / \$ 1000$
\end{tabular}

\section{General Bird Valuation Study Results}

\begin{tabular}{|c|c|c|c|c|c|c|}
\hline Naidoo \& Adamowicz & Avian Species Diversity & 2005 & Uganda & $\begin{array}{l}\text { Benefit-COST } \\
\text { ANALYSES }\end{array}$ & $\begin{array}{l}\text { Optimal Fee } \\
\text { per Entrance }\end{array}$ & $\$ 181.59$ \\
\hline Mortimer et al. & $\begin{array}{l}\text { Bird reserve on } \\
\text { offshore island }\end{array}$ & 1996 & New Zealand & CVM & Annually & $\$ 65.37$ \\
\hline Kellerman et al. & $\begin{array}{l}\text { Birds as pest control on } \\
\text { coffee plantations }\end{array}$ & 2008 & Jamaica & $\begin{array}{l}\text { Benefit-cost } \\
\text { Analyses }\end{array}$ & $\begin{array}{c}\text { Value of Pest } \\
\text { Reduction by Hectare }\end{array}$ & $\$ 163.82$ \\
\hline Crandall et al. & Birdwatcher spending & 1992 & Arizona, US & CVM & Per Visit & $\$ 150.38$ \\
\hline Stoll et al. & $\begin{array}{l}\text { Maintaining current } \\
\text { resource situation }\end{array}$ & 2006 & US & CVM & Annually & $\$ 864.76$ \\
\hline Kaval \& Loomis & Birdwatching & 2003 & US & Benefit Transfer & Per Person per Day & $\$ 62.67$ \\
\hline La Roche & Birdwatching & 2003 & US & $\begin{array}{l}\text { Benefit-cost } \\
\text { Analyses }\end{array}$ & Per Person Per Day & $\$ 326.48$ \\
\hline Hvenegaard et al. & Birdwatching & 1989 & Canada & CVM & Per Person per Day & $\$ 228.42$ \\
\hline Menkhaus \& Lober & Rare bird habitat & 1995 & Costa Rica & Travel-cost & Annually & $\$ 3856.07$ \\
\hline Colby \& Smith-Incer & $\begin{array}{l}\text { WTP for popular } \\
\text { birding reserve }\end{array}$ & 2005 & US & CVM & Annually & $\$ 279.22$ \\
\hline Brouwer et al. & $\begin{array}{l}\text { WTP migratory } \\
\text { bird protection }\end{array}$ & 2007 & Netherlands & CVM & Annually & $\$ 35.99$ \\
\hline $\begin{array}{c}\text { Sultatian \& } \\
\text { Van Beukering }\end{array}$ & $\begin{array}{l}\text { WTP migratory } \\
\text { bird protection }\end{array}$ & 2007 & Netherlands & CVM & Annually & $\$ 30.61$ \\
\hline Redhanz & $\begin{array}{l}\text { WTP to prevent decline } \\
\text { of one random bird species }\end{array}$ & 2007 & International & $\begin{array}{c}\text { Spatial } \\
\text { Econometric }\end{array}$ & Annually & $\$ 10.90$ \\
\hline Clark & $\begin{array}{l}\text { WTP to visit popular } \\
\text { birdwatching reserve }\end{array}$ & 1987 & Canada & Travel-Cost & Per Visit & $\$ 18.96$ \\
\hline Caula et al. & $\begin{array}{l}\text { WTP green spaces are } \\
\text { important for avifauna } \\
\text { conservation }\end{array}$ & 2009 & Montpellier, France & CVM & Not Reported & Not Reported \\
\hline Choong-Ki & $\begin{array}{l}\text { WTP for additional } \\
\text { diversity in bird species }\end{array}$ & 2010 & $\begin{array}{l}\text { Cheonsuman, } \\
\text { South Korea }\end{array}$ & CVM & Per Visit & $\$ 13.75$ \\
\hline Myers et al. & Birdwatching & 2010 & Delaware Bay, US & CVM & Per Household per Trip & $\$ 80.00$ \\
\hline Cooper \& Loomis & Birdwatching & 1991 & CA Residents & CVM & Per Household per Trip & $\$ 70.75$ \\
\hline Eubanks et al. & Birdwatching & 1998 & Platte River, US & CVM & Per Person per Trip & $\$ 85.00$ \\
\hline Eubanks \& Stoll & Birdwatching & 2000 & Delaware Bay, US & CVM & Per Person per Trip & $\$ 385.00$ \\
\hline Hammack \& Brown & $\begin{array}{l}\text { WTP for migratory birds } \\
\text { (waterfowl) }\end{array}$ & 1974 & US Pacific Flyway & CVM & Per Person per day & $\$ 25.00$ \\
\hline Boyle et al. & $\begin{array}{l}\text { WTP for migratory birds } \\
\text { (six species waterfowl) }\end{array}$ & 1994 & Us Central Flyway & CVM & Per Person & $\$ 149.00$ \\
\hline
\end{tabular}




\section{Appendix 2: Survey-International (Canadian and US Residents)}

Around the world people have noted with interest the emergence and temporary disappearance of many species of birds. This appearance and disappearance of birds, is mainly due to migration when the seasonal changes occur. The main factor to explain the migratory behavior of birds is the dramatic decrease in food availability. Generally in North America, four major migration routes are recognized: 1) the center route, 2) the Mississippi route, 3) the Atlantic route and 4) the Pacific route (Figure A1). Three of these pass through Mexico, in that sense it is a place of rest, feeding and/or reproduction of many species.

In the case of the route of the Centre, which brings large American birds meadows, Mexico passes through the Sierra Madre Oriental, and the Central Highland. In the passage of the Central Highland of Mexico, specifically in Mexico City, these birds feed, reproduce, rest and/or take refuge in the Protected Natural Area "Ejidos of Xochimilco and San Gregorio Atlapulco", comprising an area of 2657 hectares where are the famous Chinampas, which are highly productive prehispanic agricultural systems, made up of artificial islands. Similarly, in Xochimilco is one of the last remaining urban wetlands in the area, which similarly has great importance for the survival of birds. According to recent ornithological studies, Xochimilco has a wealth of birds amounting to about 212 species, among which there is both waterfowl and land both as Chinampas as in the wetland. Out of these 212 species, 57 have been found to nest in the area and approximately 90 of them are migratory, which mostly come from Canada and the United States. Xochimilco, like its birds, has been threatened by many factors,
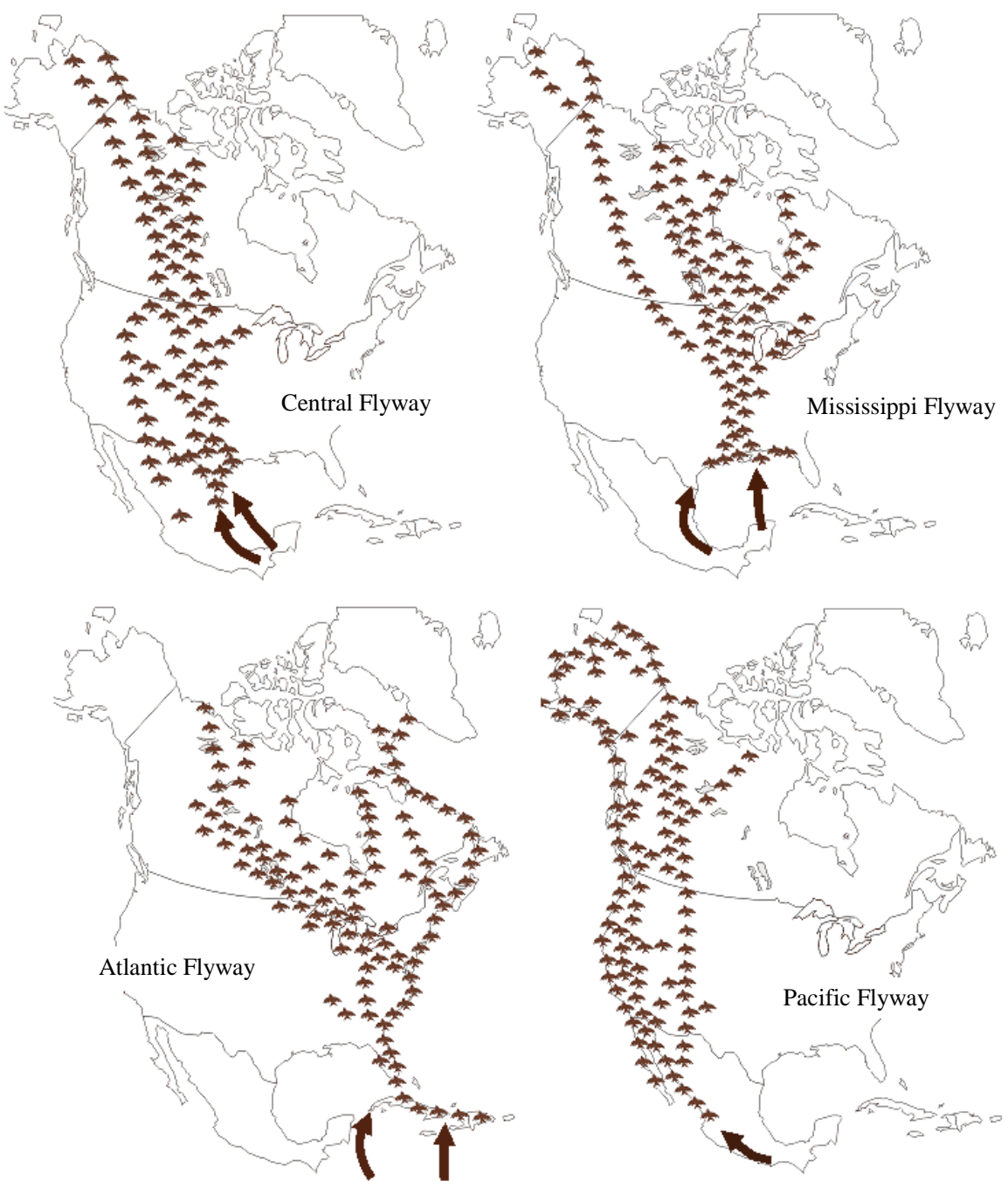

http://www.tpwd.state.tx.us/huntwild/wild/birding/migration/flyways/

Figure A1. Bird migration routes in North America to Central and South America. 
such as the invasion of urban walking, which hinders its permanence and conservation. In this regard, the following questions will try to study or identify the value or importance that people have on the conservation of a site or resting on the migration route of birds from North America to Central and South America. We must stress that the answers will be used only for research purposes.

1. For how many years have you been a birdwatcher?

2. How much time do you dedicate to this activity?

- Average number of times per month that comes to birding:

- Approximate time in minutes in a birding:

3. Have you ever gone birdwatching outside your county?

YES ( ), NO( )

4. Have you ever gone birdwatching outside your state?

YES ( ), NO( )

5. Have you ever gone birdwatching outside your country?

YES ( ), NO( )

6. How many members of you family are birdwatchers too?

7. Which of the following bundles best describe the gear you use for birdwatching?

- Binocular $8 \times 40$ (or less range), bird guide

- Binocular $8 \times 40$, bird guide, GPS whistlers/bird callers

- Binocular $10 \times 42$, bird guide, bird song identifier, whistlers/bird callers, optical/digital zoom Camera, GPS

- More/better gear than any of the above

- Less gear than any of the above

8. Do you belong to any environmental organization (birdwatching)?

$\operatorname{YES}($ ), $\mathrm{NO}(\mathrm{)}$

9. Do you agree with the following statement? "Migrating shorebird species along the Central Flyway, use specific areas like wetlands, for resting and feeding during their long journey"
YES ( ),
$\mathrm{NO}(\quad)$

10. Do you agree with the following statement? "The preservation/conservation of these resting places strongly determinates the survival of many migrating shorebird species, hence the amount of this birds to be watched"
$\operatorname{YES}(\quad)$,
NO ( )

11. In your opinion: the programs for the conservation/preservation of wetland areas along the Central Flyway (Xochimilco), as a resting place for migrating shoredird species, should be financed with:

- Mexican government funds independently

- A mutual fund cooperation between governments of Canada, Mexico and U.S.

12. Please read the following statement carefully before answering.

Suppose you are invited to participate in a project to implement a program for the conservation of wetlands and Chinampas (highly productive prehispanic agricultural systems, consisting of artificial islands) in Xochimilco (Mexico) and serve as habitat for migratory birds flying over the route of the Centre, from North America to Central and South America, in search of food, shelter, rest and a place to reproduce. Now suppose that this project would be financed jointly by the governments of Mexico, the U.S. and Canada, and by donations from 
non-governmental organizations and individuals interested in conservation. A part of economic funds come from an annual payment that would be made by birdwatchers or people interested in conservation. The project objective is to reduce to zero the net loss of wetlands and Chinampas as winter habitat for migratory birds in the Mexican portion of the route of the Centre. Please take into account the fact that if you do not live in Mexico, will receive no direct benefit from the protection of wetlands, however, you will help preserve where birds from the United States and Canada arrive. If asked, what would be the maximum amount of money you would be willing to be paid as a contribution to achieving the conservation of wetlands and Chinampas, how much would you pay " $X$ " US dollars a year?
a) YES ( ) (go to question 13)
b) NO ( ) (go to question 14)
c) Doesn't Know ( ）

13. If you answered YES: Considering you would pay at least " $\mathrm{X}$ ” US dollars a year, what would be the maximum you would be willing to pay? US dollars a year.

14. If you answered NO: Considering you would pay less than "X" US dollars a year, what would be the maximum you would be willing to pay? US dollars a year.

15. In your opinion, what would be the best payment method?
a) Payment in a website as a donation
c) Charge to membership in their observer club
$(\quad)$
b) Charge to your credit card
d) Payment in Xochimilco
e) Other ( )

16. Have you ever gone birding at Xochimilco (Mexico)?

YES ( ), NO( )

If YES, How much money did approximately the birding activity; consider all expenses such as transportation, food, entry fees, and tips, among others: USD

17. Please select your residence country

$\begin{array}{llll}\text { - CANADA } & ( & & \\ \text { - Other } & ( & \text { - USA } & (\quad)\end{array}$

18. Please select your residence state (US and Canada only)

\begin{tabular}{cccc}
\hline \multicolumn{2}{c}{ UNITED STATES OF AMERICA } & CANADA \\
\hline Alabama & Indiana & New Hampshire & Alberta \\
Alaska & Iowa & New Mexico & British Columbia \\
Arizona & Kansas & Ohio & Manitoba \\
Arkansas & Kentucky & Oklahoma & New Brunswick \\
California & Louisiana & Oregon & Newfoundland and Labrador \\
North Carolina & Maine & Pennsylvania & Nova Scotia \\
South Carolina & Maryland & Rhode Island & Ontario \\
Colorado & Massachusetts & Tennessee & Prince Edward Island \\
Connecticut & Michigan & Texas & Quebec \\
North Dakota & Minnesota & Utah & Saskatchewan \\
South Dakota & Mississippi & Vermont & Northwest Territories \\
Delaware & Missouri & Virginia & Nunavut \\
Florida & Montana & West Virginia & Yukon \\
Georgia & Nebraska & Washington & \\
Hawaii & Nevada & Wisconsin & \\
Idaho & New Jersey & Wyoming & \\
Illinois & New York & & \\
\hline
\end{tabular}


19. Which of the following options describes your educational level?

- Below highschool

( $)$

- Highschool

- Graduate

( ) - Post graduate

( )

20. The following is a personal question, but it's important for this analysis. Remember that this surveys is absolutely confidential.

- How old are you?:

- Mark with an X, the range where their income:

\section{- Gender: Man ( ）/Woman ( ）}

\begin{tabular}{ccc}
\hline & Income-US dollars/per month \\
\hline $0-500$ & $5001-5500$ & $10,001-1,0,500$ \\
$501-1000$ & $5501-6000$ & $10,501-11,000$ \\
$1001-1500$ & $6001-6500$ & $11,001-11,500$ \\
$1501-2000$ & $6501-7000$ & $11,501-12,000$ \\
$2001-2500$ & $7001-7500$ & $12,001-12,500$ \\
$2501-3000$ & $7501-8000$ & $12,501-13,000$ \\
$3001-3500$ & $8001-8500$ & $13,001-13,500$ \\
$3501-4000$ & $8501-9000$ & $13,501-14,000$ \\
$4001-4500$ & $9001-9500$ & $14,001-14,500$ \\
$4501-5000$ & $9501-10,000$ & $>14,501$ \\
\hline
\end{tabular}

